\title{
NONVERBAL EVENT AS PART OF BELIEF NARRATIVE ${ }^{1}$
}

\author{
Reet Hiiemäe
}

\begin{abstract}
A communicative act that involves the presence of two or more persons always involves a nonverbal aspect. The focus of the article is on nonverbal situations as a basis for the evolution of belief narratives. This pre-narrative aspect has not received much attention in narrative research as most analyses are based on texts that already exist in verbalised form. However, on many occasions the basis for a belief narrative is a nonverbal act that has triggered its witness or re-narrator(s) to interpret it within the framework of vernacular belief. Hence, texts that contain a nonverbal part consist of two components: 1 ) description of a nonverbal occurrence; 2) its meaning/interpretation that is verbalised by the narrator within the framework of a topical belief tradition. By bringing examples from Estonian belief narratives, the author points out some models and patterns that leap to the eye in texts narrating about nonverbal occurrences (e.g. the context of described situations, the types and results of activities described, etc.). As a theoretical basis, works on communication theory and vernacular belief research are used.
\end{abstract}

Keywords: belief narrative, narrating, nonverbal behaviour, nonverbal communication

\section{INTRODUCTION}

Studies into belief narratives are in most cases based on recordings of narrators' stories in writing. I am interested in the evolution process of such texts and, above all, the role of the nonverbal component in belief narratives. A communicative act with the presence of two or more persons always involves a nonverbal aspect, both when transmitting and receiving information (cf. Streeck \& Knapp 1992: 3), and often it seems that the folkloric narrative is based on a nonverbal situation that has inspired an eyewitness or a re-narrator to interpret the situation in terms of vernacular belief. So far this facet has remained largely outside researchers' sphere of interest, as the deductions made are bound to be somewhat hypothetical. Nevertheless, involving the nonverbal aspect enables a more complete approach to belief narratives, promising at least heuristic added value. In the following I am not trying to reconstruct exact original situ- 
ations that have engendered belief narratives, but my aim is, on the example of mainly older folklore tradition, to point out some regularities that could be observed in narrating nonverbal occurrences, as well as the circumstances that have made it possible for these narrations to persist in the tradition. The belief narrations under study originate from the manuscript collections of the Estonian Folklore Archives. In addition, I am trying to find out to what extent it is possible and efficacious, by merging communication and narrative theories and applying them to concrete archival texts, to study the nonverbal aspect in the context of belief narratives.

\section{NONVERBAL COMMUNICATION AND NARRATIVE RESEARCH: THEORETICAL STARTING POINTS}

Definitions of nonverbal communication have been proposed since the term became more widely known in the middle of the 20th century (in Estonian context e.g. Kimmel-Tenjes 1993: 536ff.). Nonverbal communication involves all ways of information transmission that people use in mutual communication in addition to the verbal part. It includes the use of gestures, facial expressions, position of body parts, movements, postures, touches, as well as aspects of information that are perceivable as inappropriate in the context (cf. Kendon 1981: 4). Already some classics of social sciences have mentioned voluntary symbolic gestures and described them as means of self-expression prior to verbal communication (e.g. Durkheim 1982 [1895]: 57ff.). More recent communication studies also emphasise that in the course of nonverbal communication information is exchanged, in addition to words, in all modalities, whereas most of the nonverbal communication takes place simultaneously with the verbal and is premeditated (Giri 2009: 690).

Communication theories predominantly focus on spontaneous communication acts rather than nonverbality in the written text or even in folktales including a supernatural component (although in a few cases definitions categorise as nonverbal communication also extrasensory perceptions; cf., e.g., Calero 2005: 280). Therefore, as expected, the study of archival texts in light of these definitions reveals a few bottlenecks; for example, it is difficult to specify telepathic contacts described in belief narratives. Mainly in memorate narratives there is a motif according to which a dead relative (e.g. mother) gives a sign to a living relative (e.g. daughter) with its appearance that someone among the living is under threat. More often than not, no direct verbal communication takes place within this kind of experience. The visionary perception of a human figure, 
interpreted as a warning from the deceased, can be treated as a nonverbal communication act; yet, decoding of the information within it takes place solely in the head of the recipient (cases with several witnesses are rather infrequent). Therefore, we cannot speak about premeditated messages but only the interpretation of the recipient, which they present by verbalising their experience.

Communication theories, when speaking about the communication process, distinguish between the sender of information and the recipient (the former transmits information and the latter receives and processes it). However, in the context of this article differentiation between these two is relevant, above all, for pointing out the fact that the information possessed by either of the parties can be of very different quality, whereas in the case of belief narratives based on nonverbal occurrences the recipient often has the key role. Sociologist Niklas Luhmann in his communication-theoretical approach also regards the recipient as more important, as it is the recipient who dictates whether and in what way information is communicated (Luhmann 1984: 191ff.). So, in the context of this article we can say that the recipient may sometimes receive information that has not been sent altogether, or not to notice or understand the information sent out. The alleged eyewitness or narrator also defines the status of the persons described in the narration, categorising them as supernatural beings, performers of magic rituals, ordinary people, etc. As in the cases I have described the more active party is the recipient, I have avoided emphasising the aspect of activeness on the sender's side and rather used, instead of the term 'nonverbal communication', concepts like 'nonverbal occurrence', 'nonverbal behaviour', or 'nonverbal situation', in order to involve also acts that do not include purposeful transmission of information (e.g. in cases when a person is not even aware of the fact that he/she is being observed and his/her nonverbal behaviour is interpreted as a magic ritual).

It is worth mentioning here that nonverbal behaviour occurs practically all the time; even complete immovability and silence can be treated as nonverbal information, and especially in the context of belief tradition silence can be very eloquent. So, as a rule, human contacts contain more nonverbal than verbal information. Several researchers studying communication have acknowledged the fact that a human being is incapable of not transmitting information with his/her behaviour and that the information the human mind uses to make decisions is predominantly nonverbal (Weisbuch \& Ambady 2008: 163-164; Giri 2009: 690). This is why it is interesting to involve the nonverbal component in the study of belief narratives. 


\section{NONVERBALITY AND BELIEF NARRATIONS: FOLKLORISTS' WORKS}

In his study on games as nonverbal folklore, published in the $1960 \mathrm{~s}$, folklorist Alan Dundes (2007) argues that, when discussing intangible heritage, we mainly bear in mind verbal folklore and study texts, but we should also explore nonverbal forms of folklore as they are similar by structure. By now Estonian scholars have published several researches on nonverbal folkloric phenomena (e.g. Kapper 2013 about traditional dance; Voolaid 2011 about droodles and graffiti). In the case of narrative folklore, the aspects of nonverbal communication and multimodality have been observed, above all, in the presentation of folklore (e.g. Voolaid 2011: 36), while multimodal communication is understood as communication involving more than two sensory modalities (verbal, activityrelated, perceived aspects) (more about the term see Tenjes 2014: 116). So the terms multimodal and nonverbal partly coincide; yet, as this research mainly focuses on the mutual influence of the verbal narration text and nonverbal occurrence, I hereinafter use the term 'nonverbal'.

So far, research into the connections between nonverbal occurrences and belief narrations has been rather scarce. The theory formulated by David Hufford (1989), who studied the nightmare phenomenon, emphasises that a folk legend describing supernatural experience is based on real-life experience, which is verbalised in the existing folklore tradition according to the established ways of formulation and description. This theory is also valid for nonverbal experiences. Madis Arukask points to the initial nonverbal nature of getting lost in folktales, saying: "Verbal expressions are but reflections of something nonverbal - of the sensory, bodily" (Arukask 2003). Ethnologist Elena Novik describes the interpretation of acoustic signals in the surroundings (e.g. crackling of fire, birdsong) as omens in the tradition of Siberian people, and concludes that the interpreted sounds are regarded as communication in terms of interaction, i.e. the sound producer's intention to transmit some kind of information or provoke reaction. In the case of narrations studied by Novik we can also, for the most part, speak about the interpretation of the recipient. Narration based on nonverbal elements also works here, as an acoustic detail could become the core of the organised storyline or its fragment (cf. Novik 2002: 107). This article, however, is not aimed at more detailed investigation of nonverbal signals as omens; it rather concentrates on nonverbal behavioural situations involving two or more persons. 
In his research into the oral presentation of the folktale Juha Pentikäinen argues, referring to Dell Hymes: "Interaction at the verbal level is not possible if the storyteller and the listener do not understand each other; that is, if they do not share a common linguistic and paralinguistic code" (Pentikäinen 1978: 242 ). It should be emphasised that in the case of nonverbal communication the shared linguistic and paralinguistic codes really exist; yet, due to this shared code (which is expressed, for example, by describing various everyday life phenomena in magic key) the belief (mis)interpretation is also possible. Daniel Hutto, who has studied narrative psychology, adds to this: "Narratives function as normalizing explanations, allowing us to cope with unusual or eccentric actions, by putting them into contexts that make them intelligible, where possible" (Hutto 2008: 7). Silvi Tenjes points out that human perception tends to classify the obtained information under certain types and categories:

If a person faces a new object, situation, or problem, they link it to their knowledge in order to classify it under a certain type. As they have classified the object, situation, or problem under a certain type, they start using the knowledge related to this type to define how to deal with this object or problem, how to behave in the novel situation. (Tenjes 2004: 155-156)

So nonverbal behaviour is understood in light of the knowledge formerly acquired by the experient, predominantly in verbalised form. Besides, the way that nonverbal activity is interpreted determines the narrative genre evolving from it: if the things experienced are perceived merely like silly behaviour, the verbalised narrative based on them may be categorised as a memorate or a funny story, yet if it is perceived as magic threat, it may rather get into circulation as a belief narrative.

\section{FROM NONVERBAL OCCURRENCE TO VERBAL NARRATIVE}

Jerome Bruner, who has studied cognitive psychology, has, among many others, presented an argument that also pertains to narrative and memory studies, declaring that people arrange their experiences and memories narratively, in the conventional form of narratives and beliefs (Bruner 1991 [1990]: 4-5). Walter Fisher, one of the creators and pillars of the theory of narrative paradigm, goes even further by claiming that any communication is narrative by its nature, as narrating renders structure to human experience and makes people shape its common interpretations and ideas. Within his theory, Fisher defines narration as "symbolic actions - words and/or deeds - that have sequence and meaning for 
those who live, create, or interpret them" (Fisher 1987: 58). Although Fisher's theory has been blamed for excessive generalisation (e.g. Benoit 1988: 536), it is relevant in the context of this article as it helps to illustrate the mutual influence of activity (or, more exactly, nonverbal behaviour) and belief narratives.

In the case of belief narratives two levels of understanding can be highlighted on the basis of nonverbal occurrence:

1) nonverbal occurrence described in the text;

2) meaning/interpretation of described events explicitly expressed by the informant.

Fisher has emphasised, as an essential criterion of narrative, its inner coherency and logicality: the narrator regards the narrative as worth narrating if he/she perceives it as coherent, whereas coherence is required both in motifs and in characters (Fisher 1987: 58). In the context of belief tradition studies it seems only justified to maintain that the pre-narrative interpretation of a nonverbal occurrence emanates from the analogy of belief and narrative coherence. The experient verbalises his/her experience depending on what they feel to be coherent in connection with their earlier beliefs. The automatic comparison of the experience to earlier known beliefs/belief narrations results in categorising the phenomenon in the same class as the belief phenomenon with the most similar features, and it is described accordingly, adding, if necessary, some missing details that are needed for understanding the occurrence. Folklorist Laura Stark also points to the observation of narrative coherence, noting that we adapt our experience according to characters that are generally narratively possible in our culture, and proceed from stereotypes and plots that our fellow men are able to recognise (Stark 2015: 118).

Nevertheless, in the case of belief narratives narrative coherence rules are not absolute, but seem to be interacting with the demands set by a concrete experience or situation, for example, perception of the level of danger. In the following example the absence of any visual sign acts as nonverbal information; namely, the experient finds confirmation to his doubts about the creature in the carriage being supernatural (the Old Nick), as he finds no footprints or other traces of him - a fact that has been repeatedly mentioned in belief narratives as a feature characteristic of supernatural beings.

A miller, the old Jaan of Käusaare, was walking along the road from Kõo through Käusaare forest. He was walking along the road and saw that there were four grey horses with a carriage, going down Joosta road, and Jaan of Käusaare thought what it might be, going down there with such big horses and a nice carriage. And he went to the road and looked 
for traces but did not find any. He was amazed and understood that it was nothing else than Old Nick. (E 29140 (37) < Pilistvere parish, 1896)

Unlike the above example, in the following text the communicative hint betraying that the woman was visited by Old Nick and her deceased husband is the existence of traces and the association with the idea that the devil has a hoof (or cloven hoof) on one or both feet.

Once upon a time a woman lived in the village of Salmistu. The woman's husband had died. One night some strangers came to visit. The strangers stayed in one room whereas the woman was pottering about in the next room. Later on the woman joined them. When the strangers left, the woman went to see them off. The others were waiting for her to return, but she did not. In the morning, when her parents went to sea, they found the woman in a fishnet. In daylight they saw in the mud the woman's footprints and horse's hoofprints. Finally the others said that her husband had gone to hell and then, together with Old Nick, had come to fetch his wife. (E 51392 $<$ Kuusalu parish, 1921)

The texts of belief narratives make us realise that the initial processing of nonverbal information takes place on the basis of basic criteria: familiar-unfamiliar, natural-supernatural, dangerous-non-dangerous. This assumption is also supported by the uncertainty reduction theory formulated by communication researchers Charles Berger and Richard Calabrese (1975: 99ff.), according to which, when meeting with strangers, the experient first observes their nonverbal behaviour and on this basis decides what to expect. In the past, in villages with sedentary lifestyle, meeting a stranger was quite rare and belief narratives served as a predisposition to consider a stranger as dangerous or supernatural or even both (cf. also Blacker 1990: 162 about perceiving a stranger as a dangerous or supernatural being). For example, in folktales both the plague spirit and the devil are often characterised with the epithet 'stranger'. Therefore being a stranger in itself was nonverbal information, which induced distrust and even hostility before the stranger was able to say or do anything. But before dwelling upon belief interpretations related to strangers, it is relevant to add some ideas about another type of nonverbal communication - silence as from the point of view of belief it can perform a special communicative role. 


\section{SILENCE AS COMMUNICATION}

Silence, the taboo against naming certain things or creatures, avoiding verbal contact in certain situations - all these are practices known in Estonian folk tradition, which were supposed to be observed especially in connection with certain periods of time (e.g. during epidemics and specific periods in the annual circle), magic rituals (e.g. predictions about the future spouse), or in places where magic influence was presumably manifested (e.g. when being alone in the forest). There were certainly plenty of rituals accompanied by incantations or other verbal forms, yet in the case of the latter the frames of interpretation were not as wide. Silent situations, on the other hand, offered highly ambivalent means of interpretation, especially in the cases when a stranger was involved; however, the incomprehensible silent action of familiar persons also increased the probability of supernatural interpretation of events. Estonian folk belief (as well as that of many other countries) regards verbal contact with a supernatural being as dangerous; that is why, when encountering a person of unclear status, it was preferable to keep silent and observe their nonverbal behaviour, in order to ascertain their further intentions or adopt preventive protective measures. In the following example, fellow men's silence is interpreted as ominous, which makes the experient launch a preventive attack on them, striking them with a cudgel.

\section{Shadow Men}

It once happened that a man came from the pub. Suddenly he noticed that two of his acquaintances, who had not been at the pub with him, were walking side by side with him. The man said hello but they did not reciprocate. He tried to talk to them but they did not respond to him. Now the man thought that the neighbours were plotting something evil against him; he grabbed a cudgel and struck them both with it. But the cudgel went as if through the air. Now they reached the forest and the two disappeared into the forest, while the man continued homewards. He should long have been home already, yet he walked until cock-crow. Only then did he see his house and understood that he had circled four times round his courtyard. (E 27327 (82) < Tartumaa, 1896)

The only supernatural interpretation expressed in the narration is the heading referring to the world of ghosts - Shadow Men; yet the specific motifs, such as the cudgel going through the body or men disappearing in the woods, are typical of traditional descriptions of ghosts, whereas walking until the cock crows and not recognising one's own home refer to the supernatural experience of getting lost. 
Coming from the pub, which is mentioned at the beginning of the story, insinuates that the experient might have been drunk and therefore in a changed state of consciousness. This might also explain why the person who came from the pub was not able to hit his neighbours (the cudgel went as if through the air) and later on lost his way. Suppose the men walking with him were his neighbours, their sudden disappearing could have been not due to their supernatural nature but rather the fact that they were not willing to continue their way with the bully. In any case, I would agree with Aado Lintrop, who has argued that in the case of a changed state of consciousness orientation to reality resulting from religious imaginations transmitted by way of folklore becomes relevant (Lintrop 2014: 16-17).

\section{STRANGERS AND THEIR ROLES IN BELIEF NARRATIVES}

The spread of folkloric phenomena and their persistence in traditional lore is guaranteed, among other things, by their openness to the different interpretations of experients/mediators/recipients. In the case of nonverbal behaviour the belief interpretation space is even wider. Below I will present the categorisation of strangers on the example of plague legends. According to legends the plague spirit used to appear in the shape of a human being, wearing ordinary clothes and looking like any other human; nothing in its appearance betrayed its dangerous nature (cf. a similar remark about the devil in Valk 1994: 19). However, sometimes belief narratives try to distinguish supernatural beings from humans on the basis of colour symbolism, for example, by claiming that both the plague and the devil wear black, whereas ghosts and spirits have been depicted as white or grey. However, we should also bear in mind that common people of the period also wore clothes of the same shades and hues. So the only facet of such beings that urged caution was them being strangers. Villagers could indeed be infected by random travellers or fugitives, so if people were taken ill after a stranger had come to a village, it was only logical that the latter was categorised under a negative status class. On the other hand, plague legends also feature neutral or positive strangers, described as random guests staying for the night, beggars, or helpers; the same appearance could refer to four different status types:

1) plague spirit;

2) harbinger of plague;

3) spreader of plague (in a few cases also depicted as a familiar person);

4) plague preventer or fighter. 
In legends all the four are connected to the outbreak of a plague epidemic and their different status is manifested only in further action (a herdboy pokes people with a stick, a random traveller gives advice, etc.); however, in quite a few cases the stranger's destiny is decided upon right after their appearance.

The stranger's destiny is determined by the alleged eyewitness of the event or the narrator (cf. Valk 2015: 426 for a similar observation about interpreting strangers as supernatural beings). So, the following text classifies one of the boys as plague and the other as a benevolent helper.

In days of yore, the lord of Rummu manor notified people that plague was coming to the village of Neeme. He ordered people to wash themselves and prepare for death. A beggar boy came to a family and asked if he could stay overnight at their place. The family told him they were going to die and could not put him up. The boy was pleading with them to take him in, then nobody would die. Finally the family decided to let him stay.

The plague was supposed to come in the form of a small boy. The lord of the manor had sent him. He had a stick in his hand with poison on one end. When the plague boy tried to enter the house through a window, the beggar boy jumped at him and killed him. So the family survived. (Hiiemäe 1997: 284)

The narrator seems to have believed that the audience did not need an explanation about why the first boy was not taken for the plague spirit, although it was known that the disease moved about in the form of a strange boy. The status of the character was not defined and was therefore open for interpretation. So the first stranger is attributed the role of a protector from the plague, which makes him a positive character. The second boy, on the other hand, is killed on the spot, making no attempt to find out whether he really intended to spread the disease or was just another travelling beggar boy.

It could be assumed that in a dangerous situation people may have projected more than one role in an unfamiliar person, which at the same time did not eliminate a complete inconsistency of these roles (Hiiemäe 2004: 71). Niklas Luhmann, when commenting on selective understanding of communicative acts, argues that each selection is contingent, i.e. possible in a different way, so the number of choices is theoretically unlimited (cited in Kõuts-Klemm 2007: 2429). In belief tradition (and probably also in other contexts) possibilities of performing a certain role are not entirely endless, as the selection has to be situation-related (or, in this case, linked to the belief that visiting strangers may indeed have caused infection), and in the context of belief narrations also coherent from the point of view of belief (or, in this case, linked to the belief 
that the spread of a disease can be terminated by killing the disease spirit). Luhmann's argument about attributing meanings to the impacts emanating from the environment is quite relevant; namely, it enables us to "either postpone our reaction or react almost instantly, as we can take over, from similar experienced situations, formerly used reactions that have already found justification" (Luhmann 1997: 45-46). In belief narratives, besides attributing meanings to situations, there is also the aspect of hereditary legitimacy, which vindicates also actions unpermitted in terms of general moral convictions (e.g. violence or even killing).

\section{NONVERBAL BEHAVIOUR AND VIOLENCE}

In the case that nonverbal signals are perceived as too menacing, the characters in belief narratives react by using protective magic or even resort to physical conflict. In a remarkable number of descriptions in the narratives the experient, deciding by the nonverbal behaviour of a fellow man, carries out a physical attack against them, as is described in the following story.

At the old sexton's place someone used to shear sheep at night-time. The old man took a cudgel, lit a candle under a bin and started watch. The door of the barn squeaked and someone came in. The sheep rumbled into another corner. The old woman started clipping with scissors. The old man pushed the bin off the candle to get more light, and beat her black and blue. She could not get out of the barn on her own feet; the old man dragged her behind the door and then went to bed.

For half a year the old woman remained bedridden; she could not tell anybody what she had done. (ERA II 254, 91/2 (29) < Käina parish, 1939)

In the above text the old woman remains silent during the whole narrative, the timeframe of which is half a year, nor does she comment on what she aimed to do; nevertheless, the narrative describing her action is characterised by figurativeness and vividness. It is a phenomenon that Laura Stark calls narrative voicelessness and which has a rhetorical function in a folktale: folktales involve certain types of characters (as, for example, alleged performers of magic and other persons deviating from social norms), who never speak about themselves and whose action is discussed only by others (cf. Stark 2015: 118ff.).

As a matter of fact, in the above text the narrator also fails to explain why in his/her opinion the old woman went to shear sheep. If she had used scissors and not sheep shears, the quantity of sheared wool could not have been 
as large as to cause economic loss worth mentioning. According to the magic beliefs of the era, if you went to shear sheep in another man's barn, your intentions may have been either harmful or harmless; for example, 1) to ruin the owner's sheep luck; 2) to make a garment guaranteeing a quick marriage (the piece of clothing was supposed to combine symbolic amounts of wool from one to nine different farms); 3) to knit mittens guaranteeing winning at court (you were supposed to knit mittens from wool sheared in nine different barns on Shrove Tuesday night and wear them to court). Principally it was possible, again based on nonverbal information, to exclude part of interpretation variants: it was presumably not Shrove Tuesday night (wool had been sheared on more than one night), and obviously the old woman was not in her prime for getting married. However, according to some texts, the girl's mother could also obtain wool for this particular ritual, so the old woman's age did not automatically exclude this version. Nevertheless, it is doubtful if the old man could have analysed the situation so thoroughly during this brief moment between the old woman's entrance and the attack; in case of suspecting danger, it was safer to react with violence immediately. From the point of view of belief interpretation, the magic explanation of the occurrence was also supported by the timeframe of the event - night-time.

\section{TEMPORAL AND SPATIAL DIMENSIONS OF AN OCCURRENCE AS NONVERBAL INFORMATION}

Several researchers studying communication add in their definitions that the environment can also transmit nonverbal 'messages' and that temporal dimensions also have to be considered (e.g. Kendon 1981: 5; Giri 2009: 693). Understanding of the nonverbal aspect of belief narrations is supported by the semantic temporal or spatial context. If a person originating from the environment of living tradition enters such a mythologically charged sphere (e.g. night-time, taboo or critical period, a specific place related to the appearance of spirits or one where magic acts are performed), they are predisposed to intensifying fear or readiness to contact with the supernatural. Probably, in the periods of plague epidemics, it made people more receptive to interpreting certain persons or groups as mythological beings (cf. Hiiemäe 2004: 69); temporal and spatial components of the same kind could also have contributed to interpreting fellow men as magic evil-doers. Here we can speak about the impact of cultural predetermination, which has been analysed by several folklorists (e.g. Honko 1972; Laagus 1973: 407-409), or - from the point of view of the communication theory - about the 'message' transmitted by the environment. 
Lauri Honko points out that in the case of a supernatural experience presented in a memorate we should also take into account the type of supernatural experience (visual, auditive, tactile, or combination thereof) and the conditions under which it is perceived (darkness, dusk, impact of monotonous stimuli, the state of the experient, such as illness, exhaustion, drunkenness, deep fear or desire) (Honko 1972: 95-96). In addition, Aado Lintrop suggests that those breaking taboos expect to have a supernatural experience pointing to punishability for an unacceptable act: "Tradition induces or causes the formation of experience; for example, a person who has deviated from a norm expects the appearance of a supernatural being as a chastener and is prone to interpret the appearing figure as such" (cf. Lintrop 2014: 17). So, according to belief lore, ghosts also have their status, rights, and obligations; they are expected to behave in a certain way, which is actualised in a situation perceived as supernatural (cf. Laagus 1973: 408).

In the following example the nonverbal component is limited to an auditively perceived sound. To enhance the credibility of the occurrence, both men's real names have been used.

It once happened that Jüri P. and Jaan K. decided to steal spruce wood; they went to the forest and started felling logs so that slivers were flying about. As soon as they were done with one spruce they took up another, working hard at it. And this was a Thursday night. But suddenly the men stopped and listened, and they heard as if the sound of hoofbeat from afar. And it came nearer and nearer. The men were terribly frightened and saw that the forest grew lighter and the cracking noise came nearer. The men hopped on their sledges and darted for Unakvere village, and never dared to come back. (E $29130<$ Pilistvere parish, 1896)

An unacceptable act performed at the magically charged time (Thursday night) and the accompanying fear correlate with the interpretation of the heard sounds in the function of a supernatural chastener. Predisposition to the intervention of the supernatural excludes the possibility of interpreting the heard hoofbeat as a sound produced by other people also stealing wood. 


\section{AUTHORITATIVENESS OF THE NARRATOR'S INTERPRETATION}

If the communicative act has two parties visible to each other, both decode their messages from the other's nonverbal behaviour. The listener of the folktale or the one who reads the written text learns only about one party's interpretation or its derivatives. In case the one being regarded as a plague spirit turned out to be an ordinary human being, he/she probably developed his/her own interpretation about the occurrence (for example an assumption that the others are drunk or raving due to an illness) when seeing the other party's odd behaviour - for example, attempts of physical attack or ritual sleeping on the floor - which have not reached us as a plague legend, yet in another lore context might have developed into a folktale. In the same way, a person suspected of having an evil eye, who was actually not trying to bewitch anybody, might have developed their own interpretation of a fellow man demonstrating their butt for parrying magic purposes or throwing salt in their wake. For instance, they might, in turn, have potentially interpreted these nonverbal acts - according to belief tradition, pursuant to which these acts may have been used also for damaging purposes - as an attempt of black magic. Magic-related explanations to acts difficult to understand were in turn supported by the fact that magic methods did not merely exist in belief and folktale world but - as several authors have emphasised (cf., e.g., Bever 2013 [2008]: 38ff.) - were practised in the pre-modern society and somewhat later also in real life. This article does not depict nonverbal behaviour endeavouring for a magic effect (e.g. bewitching by a malevolent glance) in belief narrations, which actually occurs rather often. The following memorate presents two brief episodes of nonverbal behaviour: 1) a young man offered some sweet pretzel to a girl he liked; and 2) a dog sniffed a girl under her skirt. The experient sets these activities in a framework of love magic beliefs, adding his/her own interpretation based on prior knowledge. The verbalised text is coherent with tradition and excludes the possibility that the young man may have offered the girl a piece of sweet pretzel without any magic implication or that dogs could sniff people without eating magic substances prior to that.

In the olden days people used to play pranks, fed others with various things to cast a spell on them. There was a guy who wanted me; he gave me a sweet pretzel at a fair, a beautiful white one. I did not eat it; I threw it into the Vôtikvere River. If you give it to a dog, it starts to follow you, it won't fall behind. I had a housemaid. The dog had eaten a bun she had baked; there was nothing else to do than make her leave. The dog kept 
following her, sniffing under her skirt. (ERA II 193, 113/4 (108) < Torma parish, 1938)

Here we could paraphrase a comparison made by Mikhail Lotman, replacing 'memory' by 'nonverbal behaviour', as in belief narratives the interpretation of nonverbal behaviour can evoke just as great meaning shifts:

Memory could rather be compared to a magician's hat in which you put a scarf but take out a rabbit. The only difference is that a human being I culture sincerely believes that it was the rabbit that was in the hat, and is therefore surprised by the reconstruction of the scarf. (Lotman 2012: 182-183)

\section{IN CONCLUSION}

As is shown in the above analysis, belief narratives mediate more than a precise description of a nonverbal event in narrative form. The information influencing a person at the moment of perception covers both earlier images and the situation experienced at the moment and its interpretations. So understanding of the nonverbal behaviour occurs in light of the earlier belief knowledge acquired chiefly in verbalised form. Narratives based on both verbal and nonverbal events are rather interpretations or fabrications of a situation or experience, in the course of which an insignificant event can take on a new meaning essential in terms of belief, acquiring a form suitable for spreading in narrative tradition. It is probably because in the case of nonverbal behaviour belief interpretation space is so wide that experients and narrators use repetitive concretising models. For example, the initial processing of nonverbal information seems to take place on the basis of basic criteria, such as familiar-unfamiliar, naturalsupernatural, dangerous-non-dangerous, and, depending on the results, it is followed by a neutral reaction or the usage of more passive protective measures or directly aggressive behaviour. It cannot be argued that all these folktales including a nonverbal component have been initiated by someone's real nonverbal experience; yet, it is even not important in the current context. A fact of interest worth mentioning here is that the folktale namely in this form has been regarded as corresponding to the rules of narrative coherence, and this is why it has been able to enter narrative tradition.

It holds true also about modern belief narratives that the interpretations of nonverbal behaviour described in them proceed from prior folkloric knowledge, 
presenting the shadow figures transmitting nonverbal signals as spirits of the dead, nightmares, guardian angels, or malevolent bewitchers, and, when need be, resorting to protective belief mechanisms. What has been added is the component of media impact: in hitchhiker's folklore, for instance, there are stories in which the communication act consists in merely the driver's silence and the hitchhiker's interpretation thereof, whereas the whole narrative can be built on the hitchhiker's expectation of the driver, who "looks like in a gangster movie" or "like a zombie", also to act as such. However, in the case of such extensive predisposition it is not even necessary for the driver to say or do something as the memorate of him is already born. Therefore, it is the narrator that interprets the nonverbal event and defines the status of its participants, whereas the context of the event (for instance, contexts perceived as endangering or unusual evoke supernatural interpretations more often) and the way the participants act (for instance, their silence provides the narrator with wider frames of interpretation) play a significant role in making choices at verbalising.

Changes in beliefs and alternation of theme epochs in mass media are promptly revealed also in the interpretations of nonverbal events: for instance, as the relative importance of aliens and UFOs in media coverage has diminished in the past decades, they are encountered to a lesser degree also in belief narratives. However, the process of the interpretation of nonverbal behaviour itself does not seem to have changed in belief narratives. Communication and narrative theories offer a significant framework for discussing the nonverbal aspect of belief narratives and facilitate the analysis of described interpretation processes; yet, as could have been predicted, they can be applied in such contexts only with certain reservations. For instance, in the case of belief narratives the principle of the intentionality and reciprocity of communication is often not valid; rather, the nonverbal event is interpreted unilaterally.

Translated by Tiina Mällo 


\section{NOTE}

1 This research was supported by the institutional research funding projects IUT 22-5 and IUT 2-43 and by the Centre of Excellence in Estonian Studies (CEES).

\section{MANUSCRIPT SOURCES}

E - Matthias Johann Eisen's manuscript folklore collection from the years 1880-1934 at the Estonian Literary Museum

ERA II - Folklore collection of the Estonian Folklore Archives

\section{REFERENCES}

Arukask, Madis 2003. Eksimine vadja ja setu rahvakultuuris ning folkloorse etteantuse osa selles. [The Experience of Getting Lost as Part of Votes' and Setos' Folk Culture and the Role of Cultural Predetermination in It.] In: Mare Kõiva (ed.) Artikleid usundi- ja kombeloost. [Articles about Beliefs and Customs.] Sator 2. Tartu: EKM Teaduskirjastus, pp. 96-112. Available at http://www.folklore.ee/rl/ pubte/ee/sator/sator2/Eksimine.html, last accessed on April 18, 2016.

Benoit, William L. 1988. Review. Human Communication as Narration: Toward a Philosophy of Reason, Value, and Action, by Walter R. Fisher. Argumentation, Vol. 2, No. 4, pp. 535-538.

Berger, Charles R. \& Calabrese, Richard J. 1975. Some Explorations in Initial Interaction and Beyond: Toward a Developmental Theory of Interpersonal Communication. Human Communication Research, Vol. 1, No. 2, pp. 99-112. http://dx.doi. org/10.1111/j.1468-2958.1975.tb00258.x.

Bever, Edward 2013 [2008]. The Realities of Witchcraft and Popular Magic in Early Modern Europe: Culture, Cognition and Everyday Life. Basingstoke \& New York: Palgrave Macmillan.

Blacker, Carmen 1990. The Folklore of the Stranger: A Consideration of a Disguised Wandering Saint. Folklore, Vol. 101, No. 2, pp. 162-168. http://dx.doi.org/10.10 80/0015587X.1990.9715790.

Bruner, Jerome 1991 [1990]. Acts of Meaning. Cambridge: Harvard University Press.

Calero, Henry H. 2005. The Power of Nonverbal Communication. Los Angeles \& Aberdeen: Silver Lake Publishing.

Dundes, Alan 2007. On Game Morphology: A Study of the Structure of Non-Verbal Folklore. In: Simon J. Bronner (ed.) The Meaning of Folklore: The Analytical Essays of Alan Dundes. Logan, Utah: Utah State University Press, pp. 154-163.

Durkheim, Emile 1982 [1895]. The Rules of Sociological Method. New York \& London \& Toronto \& Sydney: The Free Press. Available at http://comparsociology.com/ wp-content/uploads/2013/02/Emile-Durkheim-Rules-of-Sociological-Method-1982. pdf, last accessed on April 18, 2016. 
Fisher, Walter R. 1987. Human Communication as Narration: Toward a Philosophy of Reason, Value, and Action. Columbia: University of South Carolina Press.

Giri, Vijai N. 2009. Nonverbal Communication Theories. In: Stephen W. Littlejohn \& Karen A. Foss (eds.) Encyclopedia of Communication Theory. Thousand Oaks: SAGE Publications. http://dx.doi.org/10.4135/9781412959384.n262.

Hiiemäe, Reet 1997. Eesti katkupärimus. [Estonian Plague Lore.] Monumenta Estoniae Antiquae II. Mütoloogilised haigused I. Tartu: EKI folkloristika osakond \& EKM Eesti Rahvaluule Arhiiv.

Hiiemäe, Reet 2004. Handling Collective Fear in Folklore. Folklore: Electronic Journal of Folklore, Vol. 26, pp. 65-80. DOI: 10.7592/FEJF2004.26.hiiemae.

Honko, Lauri 1972. Uskontotieteen näkokulmia. [Perspectives of Religion.] Helsinki: WSOY.

Hufford, David J. 1989. The Terror That Comes in the Night: An Experience-Centered Study of Supernatural Assault Traditions. Philadelphia: University of Pennsylvania Press.

Hutto, Daniel D. 2008. Folk Psychological Narratives: The Sociocultural Basis of Understanding Reasons. Massachusetts: Massachusetts Institute of Technology.

Kapper, Sille 2013. Muutuv pärimustants: kontseptsioonid ja realisatsioonid Eestis 2008-2013. [Changing Traditional Folk Dance: Concepts and Realizations in Estonia 2008-2013.] Diss. (PhD thesis). Tallinn: Tallinna Ülikool, Eesti Humanitaarinstituut. Available at http://e-ait.tlulib.ee/341/1/kapper_sille.pdf, last accessed on April 18, 2016.

Kendon, Adam 1981. Introduction: Current Issues in the Study of "Nonverbal Communication". In: Adam Kendon (ed.) Nonverbal Communication, Interaction, and Gesture. Approaches to Semiotics 41. Haag: Mouton Publishers, pp. 1-54. DOI: 10.1515/9783110880021.1.

Kimmel-Tenjes, Silvi 1993. Mitteverbaalsest kommunikatsioonist. [About Nonverbal Communication.] Akadeemia, Vol. 3, pp. 535-560.

Kõuts-Klemm, Ragne 2007. Inimeseta teooria: Sissejuhatus Niklas Luhmanni autopoieetilistesse sotsiaalsetesse süsteemidesse. [A Theory without a Human: Introduction into the Autopoietic Social Systems of Niklas Luhmann.] Akadeemia, Vol. 11 (224), pp. 2412-2442.

Laagus, Aino 1973. Situatsioonianalüüsist folkloristikas. [About Situational Analysis in Folkloristics.] Keel ja Kirjandus, Vol. 7, pp. 404-412.

Lintrop, Aado 2014. Suuline pärimus uskumuste kujundajana. [Oral Tradition as a Factor that Forms Beliefs.] Loomisaja lood: Uurimusi ja tõlkeid Põhja-Euraasia rahvaste usundist. [Research into and Translations from the Belief Traditions of North Eurasian Nations.] Eesti Rahvaluule Arhiivi toimetused 32. Tartu: EKM Teaduskirjastus, pp. 13-21. Available at http://www.folklore.ee/era/pub/ files/ERAT32valik.pdf, last accessed on April 18, 2016.

Lotman, Mihhail 2012. Struktuur ja vabadus I: Semiootika vaatevinklist. 1.1. TartuMoskva koolkond: Tekstist semiosfäärini. [Structure and Freedom I: From the Viewpoint of Semiotics. 1.1. The Tartu-Moskva School: From Text to Semiosphere.] Bibliotheca controversiarum. Tallinn: Tallinna Ülikooli Kirjastus. 
Luhmann, Niklas 1984. Soziale Systeme: Grundriss einer allgemeinen Theorie. Frankfurt am Main: Suhrkamp Verlag. Available at https://steffenroth.files.wordpress. com/2012/03/soziale-systeme.pdf, last accessed on April 18, 2016.

Luhmann, Niklas 1997. Die Gesellschaft der Gesellschaft 1-2. Frankfurt am Main: Suhrkamp Verlag. Available at https://steffenroth.files.wordpress.com/2012/03/ gesellschaft-der-gesellschaft.pdf, last accessed on April 18, 2016.

Novik, Jelena 2002. Hääle semiootilised funktsioonid Siberi rahvaste folklooris ja uskumustes. [The Semiotic Functions of Voice in the Folklore and Belief of Siberian Peoples.] Mäetagused, Vol. 19, pp. 105-124. DOI: 10.7592/MT2001.19.novik.

Pentikäinen, Juha 1978. Oral Transmission of Knowledge. In. Richard M. Dorson (ed.) Folklore in the Modern World. World Anthropology. Haag: De Gruyter Mouton, pp. 237-252. DOI: 10.1515/9783110803099.237.

Stark, Laura 2015. Voicelessness and the Limits of Agency in Early Modern Finnish Narratives on Magic and the Supernatural. Narrative Culture, Vol. 2, No. 1. Available at http://digitalcommons.wayne.edu/narrative/vol2/iss1/6/, last accessed on April 18, 2016.

Streeck, Jürgen \& Knapp, Mark L. 1992. The Interaction of Visual and Verbal Features in Human Communication. In: Fernando Poyatos (ed.) Advances in Non-Verbal Communication: Sociocultural, Clinical, Esthetic and Literary Perspectives. Amsterdam \& Philadelphia: John Benjamins Publishing Company, pp. 3-23. DOI: $10.1075 /$ z.60.06str.

Tenjes, Silvi 2004. Kategooriad inimese kognitiivsel ja sotsiokultuurilisel maastikul. [Categories in the Human Cognitive and Sociocultural Landscape.] In: Helle Metslang \& Margit Langemets \& Maria-Maren Sepper (eds.) Eesti Rakenduslingvistika Ühingu aastaraamat / Estonian Papers in Applied Linguistics, pp. 155-170. http://dx.doi.org/10.5128/ERYa1.08.

Tenjes, Silvi 2014. Multimodaalne suhtlus ja kognitsiooniuuringud pedagoogikas. [Multimodal Communication and Studies of Cognition in Pedagogy.] Eesti ja soome-ugri keeleteaduse ajakiri, Vol. 5, No. 3, pp. 115-132. http://dx.doi. org/10.12697/jeful.2014.5.3.06.

Valk, Ülo 1994. Eesti rahvausu kuradi-kujutelm kristliku demonoloogia ja rahvusvahelise folkloori kontekstis: ilmumiskujud. [Image of the Devil of Estonian Folk Religion in the Context of Christian Demonology and International Folklore.] Dissertationes philologiae estonicae Universitatis Tartuensis 3. Diss. (PhD thesis). Tartu: Tartu Ülikooli Kirjastus.

Valk, Ülo 2015. Magic, Participation and Genre: Narrative Experiences of the Supernatural. In: Peeter Espak \& Märt Läänemets \& Vladimir Sazonov (eds.) When Gods Spoke: Researches and Reflections on Religious Phenomena and Artefacts. Tartu: University of Tartu Press, pp. 415-430.

Voolaid, Piret 2011. Eesti mõistatused kui pärimusliik muutuvas kultuurikontekstis. [Estonian Riddles as a Folklore Genre in a Changing Cultural Context.] Dissertationes folkloristicae Universitatis Tartuensis. Diss. (PhD thesis). Tartu: Tartu Ülikooli Kirjastus. Available at https://dspace.ut.ee/handle/10062/17528?s how=full\&locale-attribute=en, last accessed on April 18, 2016. 
Weisbuch, Max \& Ambady, Nalini 2008. Non-Conscious Routes to Building Culture: Nonverbal Components of Socialization. Journal of Consciousness Studies, Vol. 15, Nos. 10-11, pp. 159-183. Available at http://www.ingentaconnect.com/contentone/ imp/jcs/2008/00000015/F0020010/art00006, last accessed on April 18, 2016. 